\title{
Effect of amyloid beta peptide on poly(ADP-ribose) polymerase activity in adult and aged rat hippocampus ${ }^{*}$
}

\author{
Joanna B. Strosznajder ${ }^{1 凶}$, Henryk Jęśko ${ }^{1}$ and Robert P. Strosznajder ${ }^{2}$ \\ ${ }^{1}$ Department of Cellular Signalling and ${ }^{2}$ Department of Neurophysiology, Medical Research \\ Centre, Polish Academy of Sciences, A. Pawińskiego 5, 02-106 Warszawa, Poland
}

Received: 09 March, 2000; accepted: 08 May, 2000

Key words: poly(ADP-ribose) polymerase, hippocampus, amyloid, neurotoxicity, aging

\begin{abstract}
It is suggested that the fibrillar amyloid beta peptide (A $\beta$ ) in brain plays a direct role in neurodegeneration in Alzheimer's disease, probably through activation of reactive oxygen species formation. Free radicals and numerous neurotoxins elicit DNA damage that subsequently activates poly(ADP-ribose) polymerase (PARP, EC 2.4.2.30). In this study the effect of neurotoxic fragment (25-35) of full length A $\beta$ peptide on PARP activity in adult and aged rat hippocampus was investigated. In adult (4 month old) rat hippocampus the A $\beta$ 25-35 peptide significantly enhanced PARP activity by about $80 \%$ but had no effect on PARP activity in cerebral cortex and in hippocampus from aged (24-27 month old) rats. The effect of $A \beta$ peptide was reduced by half by the nitric oxide synthase inhibitor $N$-nitro-L-arginine. Stimulation of glutamate receptor(s) itself enhanced PARP activity by about $80 \%$ in adult hippocampus. However, A $\beta$ 25-35 did not exert any additional stimulatory effect. These results indicate that $\mathrm{A} \beta$, through NO and probably other free radicals, induces activation of DNA bound PARP activity exclusively in adult but not in aged hippocampus.
\end{abstract}

The neuronal deposition of amyloid beta peptides $(\mathrm{A} \beta)$ and neurofibrillary tangle formation are characteristic pathological features of Alzheimer's disease (AD). However, a fundamental question is whether the deposition of amyloid $\beta$ peptides in brain plays a direct role in neurodegeneration and cell death.
The hippocampal neurones are particularly sensitive to various types of neurotoxic agents including $\mathrm{A} \beta$ peptides. Moreover, neuronal degeneration in the hippocampus may contribute to the memory deficit observed in old people with dementia and AD. Alterations of membrane during aging and induced forma-

\footnotetext{
Supported by the State Committee for Scientific Research (KBN, Poland) grant No. 4.P05A.051.12.

${ }^{凶}$ Corresponding author: Joanna Strosznajder, tel: (48 22) 608 6414; fax: (48 22) 668 5223; e-mail: joannas@cmdik.pan.pl

Abbreviations: $\mathrm{A} \beta$, amyloid beta protein; $\mathrm{AD}$, Alzheimer disease; PARP, poly(ADP-ribose) polymerase; TBARS, thiobarbituric acid reactive substances; NNLA, $N$-nitro-L-arginine; NMDA, $N$-methyl-D-aspartic acid; p-APMSF, 4-amidinophenylmethane-sulfonyl fluoride.
} 
tion of free radicals may accelerate $\mathrm{A} \beta$ aggregation and its toxicity. Intensive studies carried out during the last decade point to the involvement of $\mathrm{A} \beta$ in neurodegenerative processes. Neurotoxicity of the fibrillar form of $\mathrm{A} \beta$ was observed in vitro [1-8]. Recently, Geula et al. [9] showed that microinjection of fibrillar $\mathrm{A} \beta$ into the aged rhesus monkey cerebral cortex caused neuronal loss, tau protein phosphorylation and microglia proliferation. These results [9] suggest that $\mathrm{A} \beta$ neurotoxicity in vivo is a pathological response of the aging brain, pronounced mainly in higher order primates. Recent studies indicate that oxidative stress and free radicals, evoked by amyloid $\beta$ peptides, are mainly responsible for the neurodegeneration and cell death [10-12].

Massive DNA damage evokes extensive stimulation of DNA bound poly(ADP-ribose) polymerase activity (PARP, EC 2.4.2.30) that can transfer up to 200 ADP-ribose groups from NAD to histones and other proteins. This extensive PARP stimulation is strongly correlated with NAD and ATP depletion and cell death. However, under physiological condition, this evolutionary conserved enzyme is involved in DNA repair and genome stability. Up till now controversial data exist on PARP activity and its level during aging [13-15]. Moreover, the effect of amyloid beta peptides on PARP activity in hippocampus as compared to cerebral cortex has not been determined until now. The aim of our studies was to investigate the mechanism of the amyloid beta dependent alteration of PARP activity in rat hippocampus from adult and aged brain.

\section{MATERIALS AND METHODS}

Wistar rats 4 months old (adult), and 24-27 months old (aged), supplied by Medical Research Centre Animal Breeding House, were used for the experiments. [Adenine $\left.-{ }^{14} \mathrm{C}\right] \mathrm{NAD}$ sp. activity: $26 \mathrm{mCi} / \mathrm{mmol}$ was obtained from Amersham (Buckinghamshire, England).
$N$-Methyl-D-aspartic acid (NMDA), $N$-nitro-L-arginine (NNLA), amyloid beta peptide 25-35 fragment and all other reagents were obtained from Sigma (St. Louis, MO, U.S.A.).

Preparation of amyloid beta peptide 25-35. Peptides were stored in lyophilized form. Stock solutions were prepared by dissolving the peptide at a concentration of 2.5 $\mathrm{mM}$ in sterile double-distilled water (vehicle). Then $\mathrm{A} \beta$ was used immediately in the non-aggregated form or incubated for 7 days at room temperature to obtain its aggregation. The presence of aggregated $\mathrm{A} \beta$ was assessed by light microscopy. Distribution of structural forms of $\mathrm{A} \beta$ was evaluated by circular dichroism (CD).

Circular dichroism spectroscopy. CD measurements were carried out with a CD62DS spectrometer equipped with a computerized data processor. Peptide samples were diluted to $25 \mu \mathrm{M}$ in double distilled water. Samples were read at room temperature in a $0.5 \mathrm{~cm}$ pathlength quartz cell. Measurements were taken over a 190 to $250 \mathrm{~nm}$ wavelength range at $5 \mathrm{~nm}$ increments.

Preparation of brain slices and homogenate. Hippocampus and cerebral cortex were isolated and then cut at $0.35 \mathrm{~mm}$ intervals in both the sagittal and coronal planes using McIlwain tissue chopper. The slices were dispersed in $15 \mathrm{ml}$ of Krebs-Henseleit buffer, pH 7.4, containing: $124 \mathrm{mM} \mathrm{NaCl}, 5$ $\mathrm{mM} \mathrm{KCl}, 26 \mathrm{mM} \mathrm{NaHCO}_{3}, 1.24 \mathrm{mM}$ $\mathrm{NaH}_{2} \mathrm{PO}_{4}, 2.4 \mathrm{mM} \mathrm{CaCl}_{2}$, and $10 \mathrm{mM}$ glucose, and centrifuged at $1100 \times \boldsymbol{g}$ for $15 \mathrm{~min}$. The pellet was resuspended in the same buffer continuously gassed with $95 \% \quad \mathrm{O}_{2} / 5 \% \mathrm{CO}_{2}$. Then the slices were preincubated for $90 \mathrm{~min}$ at $37^{\circ} \mathrm{C}$, in the absence of $\mathrm{Ca}^{2+}$ ions, for metabolic equilibration as described previously [16] and were then incubated with the agonist of glutamate receptor NMDA over the concentration range $1-100 \mu \mathrm{M}$ in the presence of $10 \mu \mathrm{M}$ glycine and $2.0 \mathrm{mM} \mathrm{CaCl}_{2}$, or in the presence of nitric oxide synthase inhibitor, $N$-nitro-L-arginine $(100 \mu \mathrm{M})$ for $15 \mathrm{~min}$ at $37^{\circ} \mathrm{C}$. In other experiments the slices were in- 
cubated for $20 \mathrm{~min}$ or $60 \mathrm{~min}$, in the presence of $2 \mathrm{mM} \mathrm{CaCl}_{2}$ with either the non-aggregated or aggregated form of $\mathrm{A} \beta$ peptide $25-35$ over the concentration range of $1-25 \mu \mathrm{M}$. After incubation the slices were homogenised and used for determination of PARP activity or of thiobarbituric acid reactive substances (TBARS).

Determination of PARP activity. The PARP activity was determined using [adenine ${ }^{14} \mathrm{C}$ NAD as a substrate. The incubation mixture in a final volume of $100 \mu \mathrm{l}$ contained: $200 \mu \mathrm{M}\left[{ }^{14} \mathrm{C}\right] \mathrm{NAD} 2 \times 10^{5}$ d.p.m., $100 \mathrm{mM}$ Tris/ $\mathrm{HCl}$ buffer, $\mathrm{pH}$ 8.0, $10 \mathrm{mM} \mathrm{MgCl} 2,1 \mathrm{mM}$ dithiothreitol (DTT), $50 \mu \mathrm{M}$ 4-amidinophenylmethane-sulfonyl fluoride (p-APMSF) and 200 $\mu \mathrm{g}$ of protein. The mixture was incubated for 5 $\min$ at $37^{\circ} \mathrm{C}$, then the reaction was stopped by adding $0.8 \mathrm{ml}$ of ice-cold $25 \%$ trichloroacetic acid. Precipitates were collected on Whatman GF/B filters and washed 3 times with the $5 \%$ acid. The radioactivity was determined using LKB Wallac 1409 scintillation counter.

Determination of thiobarbituric acid reactive substances. Thiobarbituric acid reactive substances including malondialdehyde, the last product of lipid peroxidation, were determined according to Asakawa \& Matsushita [17]. The hippocampal slices were preincubated for $90 \mathrm{~min}$ at $37^{\circ} \mathrm{C}$ and then were incubated for 20 or 60 min with or without $25 \mu \mathrm{M}$ $\mathrm{A} \beta$. Then the slices were homogenized in ice cold $10 \mathrm{mM}$ Tris/HCl buffer, $\mathrm{pH}$ 7.4. The homogenates were resuspended in $10 \mathrm{mM}$ Tris/HCl buffer, $\mathrm{pH} 7.4$, at protein concentrations of approximately $0.5 \mathrm{mg} / \mathrm{ml}$ and were incubated for $5 \mathrm{~min}$. After incubation $1 \mathrm{ml}$ of $30 \%$ trichloroacetic acid, $0.1 \mathrm{ml}$ of $5 \mathrm{M} \mathrm{HCl}$ and $0.75 \%$ thiobarbituric acid were added. The tubes were capped and the mixture was heated at $100^{\circ} \mathrm{C}$ for $15 \mathrm{~min}$ in a boiling water bath. After centrifugation the absorbance of the supernatant was determined at $535 \mathrm{~nm}$ against the reagent blank.

The research project was accepted by the Institutional Ethics Committee.

\section{RESULTS}

The agonist of glutamate receptor (NMDA) at $100 \mu \mathrm{M}$ concentration enhanced PARP activity by about $80 \%$ in adult rat hippocampus but not in aged hippocampus and cerebral cortex (Fig. 1). This NMDA-evoked stimulation of PARP activity was decreased by the inhibitor of NO synthase, $N$-nitro-L-arginine (NNLA) (Fig. 1). NMDA at lower concentrations $(1 \mu \mathrm{M}$ or $10 \mu \mathrm{M}$ ) had an insignificant stimulatory effect on PARP activity. In the experimental condition, activation of glutamatergic receptor by NMDA $(100 \mu \mathrm{M})$ did not stimulate lipid peroxidation processes determined as TBARS (not shown). For the determination of the effect of amyloid beta peptide on PARP activity, the neurotoxic $\mathrm{A} \beta$ fragment $25-35$ at $25 \mu \mathrm{M}$ final concentration was used. The fresh $\mathrm{A} \beta$ analyzed by CD spectroscopy had mainly a random coil structure. The aggregated form of the peptide had a beta sheet structure. $\mathrm{A} \beta$ peptide 25-35, exclusively in the aggregated form, significantly stimulated PARP activity in hippocampus slices from adult rats (4 months old) (Fig. 2), while free radical dependent lipid peroxidation determined as TBARS was unchanged (Table 1). In cerebral cortex $\mathrm{A} \beta$ had no effect on PARP activity. The amyloid beta peptide evoked PARP stimula-

Table 1. Effect of A $\beta$ peptide 25-35 on TBARS concentration in rat hippocampus.

Hippocampal slices from 4 month old rats were preincubated for $90 \mathrm{~min}$ at $37^{\circ} \mathrm{C}$ and then incubated for 20 or 60 min with or without $25 \mu \mathrm{M} \mathrm{A} \beta$ peptide $25-35$. TBARS were determined as described in Material and Methods. The results are mean \pm SEM from 3 experiments carried out in triplicate.

\begin{tabular}{lll}
\hline \multicolumn{2}{l}{ Experimental condition } & TBARS \\
\cline { 1 - 2 } Time (min) & Addition of $\mathrm{A} \beta$ & $\mathrm{nmol} / \mathrm{mg}$ protein \\
\hline 0 & - & $0.83 \pm 0.08$ \\
20 & - & $3.04 \pm 0.26$ \\
20 & + & $2.59 \pm 0.14$ \\
60 & - & $2.76 \pm 0.18$ \\
60 & + & $2.77 \pm 0.28$ \\
\hline
\end{tabular}



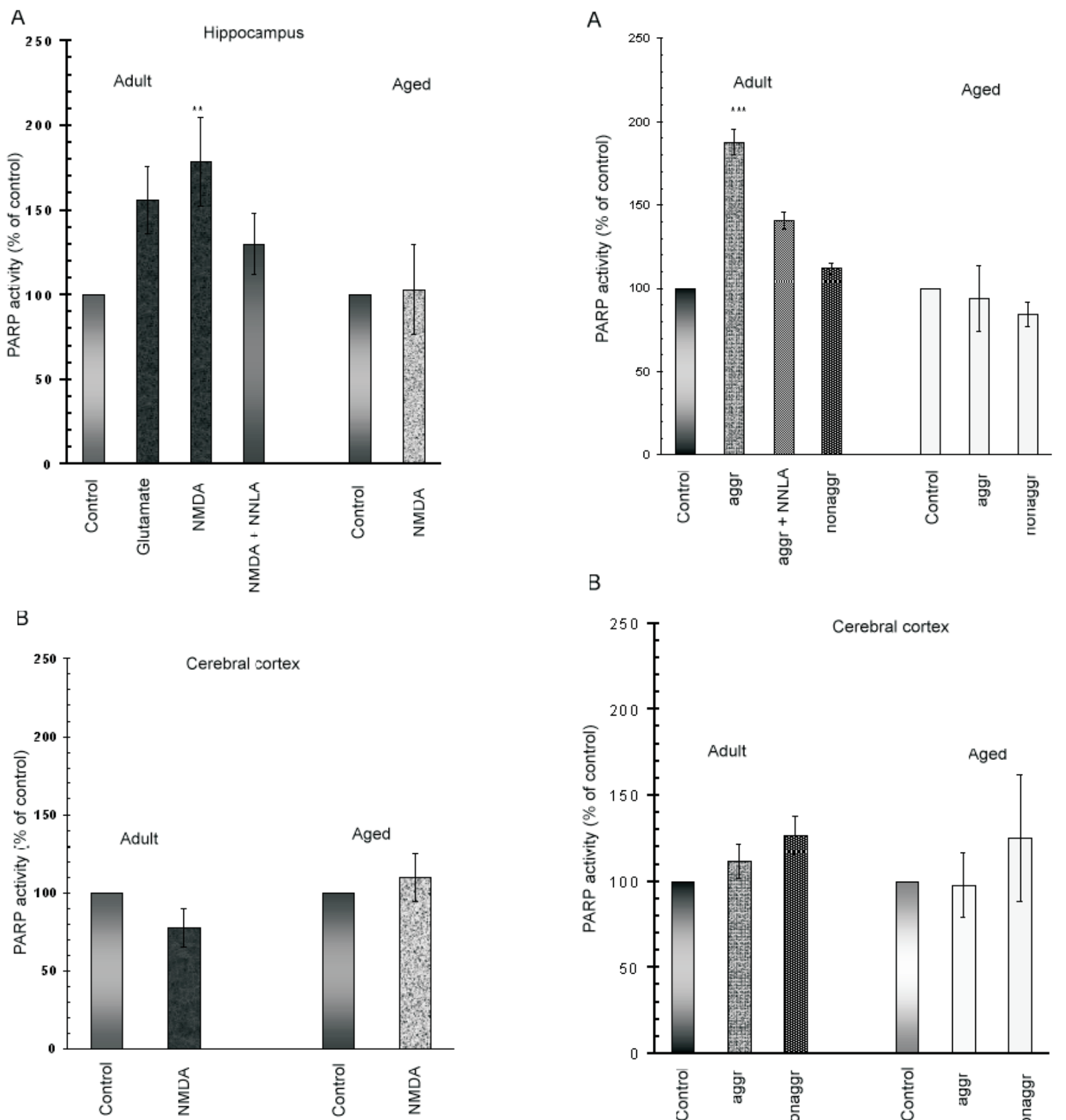

Figure 1. Effect of NMDA on PARP activity in adult and aged rat hippocampus (A) and cerebral cortex (B).

Brain slices were preincubated for $90 \mathrm{~min}$ at $37^{\circ} \mathrm{C}$. In some experiments $100 \mu \mathrm{M}$ NNLA was added for the last $15 \mathrm{~min}$ of preincubation. Then the slices were incubated separately with $100 \mu \mathrm{M}$ NMDA or $1 \mathrm{mM}$ glutamate for 15 min at $37^{\circ} \mathrm{C}$, homogenized and PARP activity was determined. Data are means \pm SEM from 3-7 experiments carried out in triplicate. The data for cerebral cortex and for glutamate are means \pm SEM from one typical experiment carried out in triplicate. Statistical significance was evaluated by Student $t$-test, ${ }^{* *} P$ $<0.02$ as compared to control, i.e. PARP activity in unstimulated conditions taken as 100.

B

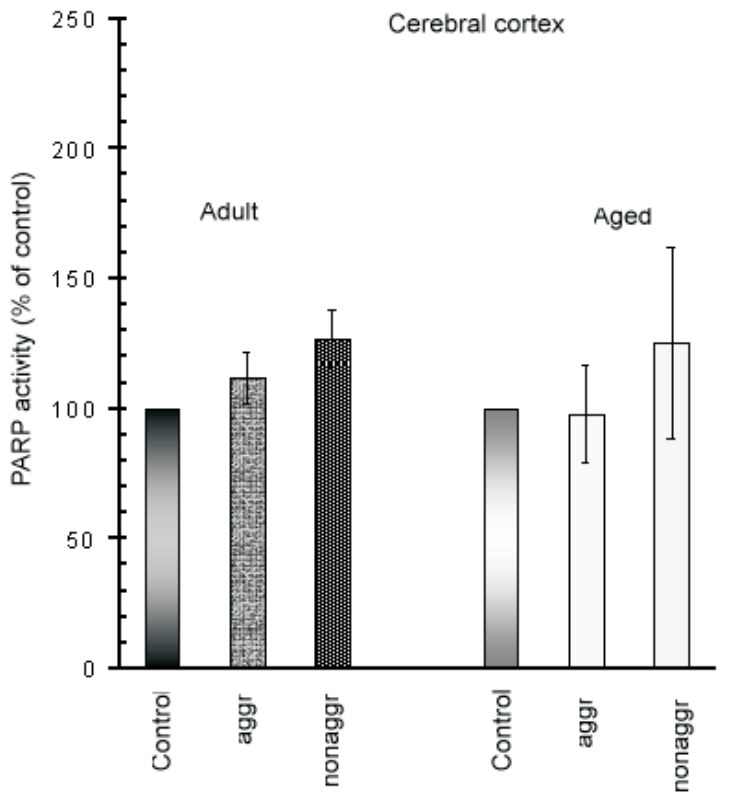

Figure 2. Effect of aggregated and non-aggregated $\mathrm{A} \beta$ peptide 25-35 on PARP activity in adult and aged rat hippocampus (A) and cerebral cortex (B).

Brain slices were preincubated for $90 \mathrm{~min}$ at $37^{\circ} \mathrm{C}$ then were incubated $\left(20 \mathrm{~min}, 37^{\circ} \mathrm{C}\right.$ ) with $25 \mu \mathrm{M} \mathrm{A} \beta(25-35)$. In some experiments $100 \mu \mathrm{M}$ NNLA was added for the last 15 min of preincubation. Brain slices were homogenized and PARP activity was determined. Data are means \pm SEM from 3-5 experiments carried out in triplicate. The data for cerebral cortex are means \pm SEM from one typical experiment carried out in triplicate. Statistical significance was evaluated by Student $t$-test, ${ }^{* * *} P<0.001,{ }^{\ddagger} P<0.001$ as compared to control, i.e. PARP activity in unstimulated conditions or 
tion in adult hippocampus was significantly decreased by NNLA (Fig. 2). In hippocampal slices from aged brain (24-27 month old rats), the A $\beta$ peptide 25-35 had no effect on PARP activity (Fig. 2) and did not exert any additional stimulatory effect on the NMDA receptor which enhanced PARP activity in adult hippocampus (not shown).

\section{DISCUSSION}

Our results indicate that the glutamate receptor agonist, NMDA enhanced PARP activity in hippocampal slices from adult rats. However, NMDA had no effect on PARP activity in brain cortex and in aged hippocampus. One of the reasons for these differences could be a lower density of glutamate receptor(s) in cerebral cortex and in aged hippocampus as compared to adult hippocampus. It is possible that the NMDA evoked PARP stimulation is connected with DNA damage, that can not be detected by the currently available methods [18]. However, extensive stimulation of NMDA may induce detectable DNA damage, neurodegeneration and cell death. The role of excessive stimulation of NMDA receptor in cerebral ischemia is well known and documented [19, 20]. Nitric oxide synthase activity is elevated after NMDA receptor stimulation $[21,22]$. Liberation of $\mathrm{NO}^{\bullet}$ and $\mathrm{ONOO}^{-}$can lead to the impairment of membrane phospholipids, mitochondrial proteins and DNA [23-25]. It has been shown that DNA damage after ischemic insults may activate PARP [18, 26]. Zhang et al. [27] found that PARP inhibitors blocked the NMDA and NO mediated neurotoxicity. Moreover, there are also suggestions that neurodegeneration evoked by amyloid beta peptide may depend on its influence on glutamate receptors [28, 29]. Our data showed that the neurotoxic amyloid beta fragment 25-35 enhanced PARP activity in adult hippocampus. Significantly lower PARP activity observed in aged hippocampus [30] may be responsible for the lack of the effect of $\mathrm{A} \beta$ (25-35) on this enzyme. It is worth noting that neurotoxicity of amyloid beta peptide depends on its conformation and aggregation state as well as on its final concentration and duration of the treatment [1, 31, 32]. Our results indicated that amyloid beta peptide exclusively in aggregated form had a stimulatory effect on PARP activity. Numerous data showed a strong $\mathrm{A} \beta$ neurotoxicity both in in vitro and in vivo experiments [1, 5, 31, 33-36]. However, other authors reported that $\mathrm{A} \beta$ produced but a small neurotoxic effect $[4,28,30,37,38]$. Our results suggest that glutamate receptor(s) may be involved in A $\beta$ evoked PARP activity. However, when amyloid peptide acted together with NMDA the stimulatory effect of NMDA on PARP activity was not increased in adult hippocampus. Gray \& Patel [39] showed that amyloid beta did not alter the potency of glutamate excitotoxicity in cultured neurones exposed to $\mathrm{A} \beta$ peptide $25-35$ together with glutamate. We showed that the effect of $\mathrm{A} \beta$ peptide on PARP activity in adult hippocampus was decreased by the inhibitor of NO synthase. This implies that $\mathrm{A} \beta$, through $\mathrm{NO}^{\bullet}$ and probably other free radicals, is involved in activation of PARP in adult hippocampus.

We are grateful to Mrs M.D. Kacprzak for the excellent technical assistance and Mrs Beata Łuczyńska for preparation of the manuscript.

\section{R E F E R E N C E S}

1. Pike, C.J., Walencewicz, A.J., Glabe, C.G. \& Cotman, C.W. (1991) In vitro aging of $\beta$-amyloid protein causes peptide aggregation and neurotoxicity. Brain Res. 563, 311-314.

2. Pike, C.J., Ramezan-Arab, N. \& Cotman, C.W. (1997) Beta-amyloid neurotoxicity in vitro: Evidence of oxidative stress but not protection by antioxidants. J. Neurochem. 69, 1601-1611. 
3. Mattson, M.P., Tomaselli, K.J. \& Rydel, R.E. (1993) Calcium-destabilizing and neurodegenerative effects of aggregated $\beta$-amyloid peptide are attenuated by basic FGF. Brain Res. 621, 35-49.

4. Busciglio, J., Lorenzo, A. \& Yankner, B.A. (1992) Methodological variables in the assessment of beta amyloid neurotoxicity. Neurobiol. Aging 13, 609-612.

5. Yankner, B.A., Duffy, L.K. \& Kirschner, D.A. (1990) Neurotrophic and neurotoxic effects of amyloid $\beta$ protein: Reversal by tachykinin neuropeptides. Science 250, 279-282.

6. Strosznajder, J.B., Zambrzycka, A., Kacprzak, M.D. \& Strosznajder, R.P. (1999) Amyloid $\beta$ peptide 25-35 modulates hydrolysis of phosphoinositides by membrane phospholipase(s) C of adult brain cortex. J. Mol. Neurosci. 12, 101-109.

7. Zambrzycka, A., Strosznajder, R.P. \& Strosznajder, J.B. (2000) Aggregated beta amyloid peptide 1-40 decreases $\mathrm{Ca}^{2+}$ - and cholinergic receptor-mediated phosphoinositide degradation by alteration of membrane and cytosolic phospholipase $\mathrm{C}$ in brain cortex. Neurochem. Res. 25, 189-196.

8. Mattson, M.P., Partin, J. \& Begley, J.G. (1998) Amyloid-beta peptide induces apoptosis-related events in synapses and dendrites. Brain Res. 807, 167-176.

9. Geula, C., Wu, C.K., Saroff, D., Lorenzo, A., Yuan, M.L. \& Yankner, B.A. (1998) Aging renders the brain vulnerable to amyloid beta-protein neurotoxicity Nature Medicine 4, 827831.

10. Markesbery, W.R. (1997) Oxidative stress hypothesis in Alzheimer's disease. Free Radical Biol. Med. 23, 134-147.

11. Butterfield, D.A., Yatin, S.M., Varadarajan, S. \& Koppal, T. (1999) Amyloid beta-peptide-as- sociated free radical oxidative stress, neurotoxicity, and Alzheimer's disease. Methods Enzymol. 309, 746-768.

12. Butterfield, D.A., Howard, B., Yatin, S., Koppal, T., Drake, J., Hensley, K., Aksenov, M., Aksenova, M., Subramaniam, R., Varadarajan, S., Harris-White, M.E., Pedigo, N.W., Jr. \& Carney, J.M. (1999) Elevated oxidative stress in models of normal brain aging and Alzheimer's disease. Life Sci. 65, 1883-1892.

13. Grube, K. \& Burkle, A. (1992) Poly(ADPribose) polymerase activity in mononuclear leukocytes of 13 mammalian species correlates with species-specific life span. Proc. Natl. Acad. Sci. U.S.A. 89, 11759-11763.

14. Muiras, M.L., Muller, M., Schachter, F. \& Burkle, A. (1998) Increased poly(ADP-ribose) polymerase activity in lymphoblastoid cell lines from centenarians. J. Mol. Med. 76, 346-354.

15. Mishra, S.K. \& Das, B.R. (1992) (ADP-ribosyl)ation pattern of chromosomal proteins during ageing. Cell. Mol. Biol. 38, 457-462.

16. Chalimoniuk, M. \& Strosznajder, J.B. (1998) Aging modulates nitric oxide synthesis and cGMP levels in hippocampus and cerebellum: Effects of amyloid $\beta$ peptide. Mol. Chem. Neuropathol. 35, 77-95.

17. Asakawa, T. \& Matsushita S. (1980) Coloring conditions of thiobarbituric acid test for detecting lipid peroxides. Lipids 15, 137-140.

18. Zhang, J., Pieper, A. \& Snyder, S.H. (1995) Poly(ADP-ribose) synthetase activation: An early indicator of neurotoxic DNA damage. $J$. Neurochem. 65, 1411-1414.

19. Choi, D.W. (1992) Excitotoxic cell death. J. Neurobiol. 23, 1261-1276.

20. Rothman, S.M. \& Olney, J.W. (1986) Glutamate and the patophysiology of hypoxic- 
ischemic brain damage. Ann. Neurol. 19, 105-111.

21. Chalimoniuk, M. \& Strosznajder, J. (1998) NMDA receptor-dependent nitric oxide and cGMP synthesis in brain hemispheres and cerebellum during reperfusion after transient forebrain ischemia in gerbils: Effect of 7-nitroindazole. J. Neurosci. Res. 54, 681-690.

22. Dawson, V.L., Dawson, T.M., London, E.D., Bredt, D.S. \& Snyder, S.H. (1991) Nitric oxide mediates glutamate neurotoxicity in primary cortical cultures. Proc. Natl. Acad. Sci. U.S.A. 88, 6368-6371.

23. Dawson, D.A. (1994) Nitric oxide and focal cerebral ischemia: Multiplicity of actions and diverse outcome. Cerebrovasc. Brain Metab. Rev. 6, 299-324.

24. Beckamn, J.S. (1994) Peroxynitrite vs hydroxyl radical: The role of $\mathrm{NO}$ in superoxide-mediated cerebral injury. Ann. N.Y. Acad. Sci. 738, 69-75.

25. Chan, P.H. (1996) Role of oxidants in ischemic brain damage. Stroke 27, 1124-1129.

26. Love, S., Barber, R. \& Wilcock, G.K. (1999) Neuronal accumulation of poly(ADP-ribose) after brain ischemia. Neurophat. App. Neurobiol. 25, 98-103.

27. Zhang, J., Dawson, V.L., Dawson, T.M. \& Snyder, S.H. (1994) Nitric oxide activation of poly(ADP-ribose) synthetase in neurotoxicity. Science 263, 687-689.

28. Le, W.D., Colom, L.V., Xie, W.J., Smith, R.G., Alexianu, M. \& Appel, S.H. (1994) Cell death induced by $\beta$-amyloid $1-40$ in MES 23.5 hybrid clone: The role of nitric oxide and NMDAgated channel activation leading to apoptosis. Brain Res. 686, 49-60.

29. Mattson, M.P., Cheng, B., Davis, D., Bryant, K., Lieberburg, I. \& Rydel, R.E. (1992) $\beta$-Amyloid peptides destabilize calcium homeostasis and render human cortical neurons vulnerable to excitotoxicity. J. Neurosci. 12, 376-389.

30.Strosznajder, J., Jęśko, H. \& Strosznajder, R.P. (2000) Age-related alteration of poly(ADP-ribose) polymerase activity in different parts of the brain. Acta Biochim. Polon. 47, $331-337$.

31. Pike, C.J., Burdick, D., Walencewicz, A.J., Glabe, C.G. \& Cotman, C.W. (1993) Neurodegeneration induced by beta-amyloid peptides in vitro: The role of peptide assembly state. J. Neurosci. 13, 1676-1687.

32. Pike, C.J., Overman, M.J. \& Cotman, C.W. (1995) Amino-terminal deletions enhance aggregation of beta-amyloid peptides in vitro. $J$. Biol. Chem. 270, 23895-23898.

33. Roher, A.E., Ball, M.J., Bhave, S.V. \& Wakade, A.R. (1991) $\beta$-Amyloid from Alzheimer disease brains inhibits sprouting and survival of sympathetic neurons. Biochem. Biophys. Res. Commun. 174, 572-579.

34.Emre, M., Geula, C., Ransil, B.J. \& Mesulam, M.M. (1992) The acute neurotoxicity and effects upon cholinergic axons of intracerebrally injected $\beta$-amyloid in the rat brain. Neurobiol. Aging 13, 553-559.

35. Frautschy, S.A., Baird, A. \& Cole, G.M. (1991) Effects of injected Alzheimer's $\beta$-amyloid cores in rat brain. Proc. Natl. Acad. Sci. U.S.A. 88, 8362-8366.

36. Kowall, N.W., Beal, M.B., Busciglio, J., Duffy, L.K. \& Yankner, B.A. (1991) An in vivo model for the neurodegenerative effects of $\beta$ amyloid and protection by substance P. Proc. Natl. Acad. Sci U.S.A. 88, 7247-7251.

37. Games, D., Khan, K.M., Soriano, F.G., Keim, P.S., Davis, D.L., Bryant, K. \& Lieberburg, I. (1992) Lack of Alzheimer pathology after $\beta$-amyloid protein injections in rat brain. Neurobiol. Aging 13, 569-576. 
38. Podlisny, M.B., Stephenson, D.T., Frosch, M.P., Tolan, D.R., Lieberburg, I., Clemens, J.A. \& Selkoe, D.J. (1993) Microinjection of synthetic amyloid $\beta$-protein in monkey cerebral cortex fails to produce acute neurotoxicity. Am. J. Pathol. 142, 17-24.
39. Gray, C.W. \& Patel, A.J. (1995) Neurodegeneration mediated by glutamate and beta-amyloid peptide: A comparison and possible interaction. Brain Res. 691, 169-179. 